Article

\title{
The Divine Gaps between the Usuli and Akhbaris in Bahrain: Causes and Repercussions
}

\author{
Rashed Alrasheed $\mathbb{D}$ \\ Fellow at the Richardson Institute, Lancaster University, Lancaster LA1 4YL, UK; zainrashedeen@gmail.com \\ Received: 25 April 2020; Accepted: 24 June 2020; Published: 30 June 2020 \\ check for \\ updates
}

\begin{abstract}
In any analysis of Bahrain's political structure, it is fundamental to understand the relationship between the Usili, Akhbaris, and authority. This analysis includes an assessment of the implications of the differences between the Usili and Akhbaris, thus shedding light on the dynamic interaction between these players in local and external structures and clarifying the effect of ideology and identity on the ties of authority with Shi'a. Usuli and Akhbaris principles have incontrovertible implications for the political perceptions of Shi'a groups and elites with regard to their dealings with the government in Bahrain. These religious perceptions form part of the political equation involved in ensuring the convergence of authority with the Shi'a community. This paper considers how differences between the Usuli and Akhbaris have shaped the relation between authority and Shi'a in Bahrain.
\end{abstract}

Keywords: Usuli; Akhbaris; Bahrain; Shi'a; Iran

\section{Introduction}

Although there are Shi'a actors like $U s u l i^{1}$, who are against Bahrain's authority on religious, social, and political grounds, not all Shi'a oppose Bahrain's authority. In addition, not all Bahraini Shi'a follow the Supreme Leader, and not all of them are loyal to Iran. Friedman (2012, p. 76) confirmed that not all Shi'a in Bahrain seek to establish a state such as the Iranian model Wilayat Al-Faqih. However, much less is known about the Akhbaris ${ }^{2}$ Shi'a group, which is allied politically with the authority.

The authority has, in fact, benefited from religious rivalry and complex dynamic interaction between Usuli and Akhbaris, which has led to the rapprochement of authority with some of the Shi'a groups in the State. Therefore, it is necessary to analyze contradictory identities within the Shi'ite community, in order to understand the relationship between society, the regime, and the State.

For example, it is widely held that the ethnic, religious, and intellectual dissonance between the Usuli and Akhbaris has expanded the gap in the Shi'i community, with this disharmony becoming an influential factor in shaping the relationship between Shi'a forces and the authority (Fahmy 2008, 2011; Yateem 2016). Analyzing the rivalry between the Usuli and Akhbaris helps shed light on the implications of Persian identity for the Usuli, the Shi'i doctrine itself, and Arab Shi'i identity in Bahrain, considering that Iran has played a key role in reinforcing the influence of the Usuli in Bahrain in contemporary history. However, the prime objective of this paper is to answer the following research question: To what extent do the religious and political differences between the Usuli and Akhbaris have a political meaning?

1 Usuli is a School of Islamic jurisprudence, which draws upon the philosophies, jurisprudence, and diligence of Shi'a clerics as a source of Islamic legislation (Cole 1987, p. 196).

2 Akhbaris is a Shi'a school of Islamic thought, which uses the legacy of the Imams in the form of religious texts and speeches as a source of legislation (Eliash 1979, pp. 12-16). 
This study presents a sophisticated path toward explaining the religious and political differences between Shi'a groups through addressing the impact of rivalry between the Usuli and Akhbaris on the convergence of authority with the Shi'i community in Bahrain. This was achieved by interviewing a sample of 24 study participants in Bahrain as a means of explaining the difference between the Usuli and Akhbaris that will enable the reader to understand how the authority has benefited from this dispute to enhance its affinity with the Shi'a community.

Some of the interviews were conducted with participants who had been engaged in political life, but did not belong to any political parties or worked in government (see Appendix A). These included journalists, academics, two Sunni clerics, one Akhbaris cleric, and one Usuli cleric, who were able to provide diverse and unbiased information for this project. The rationale behind conducting elite interviews was therefore to engage with distinguished individuals who possessed expertise in the topic under study. Moreover, these elite participants were selected purposively, rather than randomly, because their expertise would ensure that worthwhile information was gathered (Harrison 2001, p. 94). Thus, several interviews were conducted with political leaders, politicians, representatives from NGOs, and religious leaders. To recruit these participants, the researcher sent out invitations and a participant information sheet in Arabic to potential respondents via email to their personal, university, or parliamentary websites as well as contacting them through social media. Once a participant had accepted an invitation, they were asked to suggest a convenient day and time for an interview. The same recruitment procedure was used for all of the participants.

NVivo (qualitative data analysis software was used and the research questions were addressed effectively by illustrating the recorded data and concentrating on specific aspects of the article inquiry, as demonstrated in the interview transcripts. Within this context, the researcher used analytical models via NVivo to process the interview information by coding and arranging the data, in order to identify commonalities and differences in the main themes. Focus was given to cases with similar results, effects and causes; reducing the data within the framework of the main theme. After this analysis, the information was illustrated and evaluated before the whole process was reiterated until answers were found to the research questions, drawing comparisons between the data and themes to produce a significant result. Theme-coding was the method adopted in this paper as a means of recognizing and classifying statements and information or arranging a set of ideas. The researcher coded the interview data to derive research themes that informed the research questions. These research themes originated from a review of the relevant literature and secondary sources. Open coding was applied to regulate, isolate, and label information in the transcript. This determined which themes were significant and which required further analysis. Likewise, coding was applied to compare and classify the interview data from different perspectives. Moreover, within this process, the researcher looked for patterns in the data themes and used themes as the foundation of the data analysis (Saldana 2015, p. 12).

The researcher was obligated to respect the participants' privacy, in accordance with the ethical procedures for the Faculty of Arts and Social Sciences, and the Management School's Research Ethics Committee at Lancaster University (FASS-LUMS REC). The interviewees were subsequently notified that their names would not be recognizable from the paper, as they would be anonymized in a default procedure. Nevertheless, all the participants in this project wished to remain anonymous due to the sensitivity of the topic.

\section{The Demographic Composition of Bahrain}

Bahrain is the smallest of the Gulf States, located on an archipelago in the Persian Gulf ${ }^{3}$, lying in Western Asia to the east of Saudi Arabia. It therefore shares a maritime border with Iran in the north

3 There is no agreement on the name of this Gulf. In the Gulf States, it is called the Arabian Gulf, while in Iran, the UN, USA, and UK, it is referred to as the Persian Gulf. The dispute over its name is integral to the political, ethnic and religious differences between Iran and the Gulf States. The Arab countries object to the designation of the Persian Gulf in UN documents and electronic networks, such as Google. 
and Qatar to the southeast. According to UN Data World Information (2018), the population of Bahrain is around 1569.439 million, although more than half of its inhabitants are non-nationals. Furthermore, in 2014, it was estimated that $70.2 \%$ of the population were Muslims, $10.2 \%$ were Christians, and nearly $0.21 \%$ were Jews (Ministry of Information Affairs 2014). Aside from this, approximately $19.5 \%$ were anticipated to be Hindus, Baha'is, Buddhists, and Sikhs, these mainly being immigrants from South Asia (Ministry of Information Affairs 2014). The population as a whole is distributed across four provinces: Manama (the capital), Muharraq, Northern, and Southern.

There is no official census from the Bahraini government, or from any international organizations, confirming the proportion of Shi'a to Sunnis in Bahrain as well as Usuli vs. Akhbaris. However, the Al Jazeera Media Network revealed an official document issued in 2010 by the Bahraini government, which showed that the percentage of Sunni citizens amounted to $51 \%$, while the proportion of Shi'a totaled 49\% (Al Jazeera Media Network 2017). The demographic challenge in Bahrain always creates political tension in the community, because social structure and identity are an integral part of the regional competition equation between Saudi Arabia and Iran. However, in 1920, the British authorities estimated the population of Bahrain to be no more than 100,000, comprising 60,000 Sunnis and 40,000 Shi'a. In 1940, the number of Shi'a totaled 46,359, while Sunnis were slightly outnumbered at 41,984 (Al Rumaihi 1975, p. 245). By 1950, the total population of Bahrain was 125,000, half of whom were Shi'a (The UK National Archives 1959, BA1083/4 (59)). Nevertheless, many scholars (such as Bill 1984, p. 120; Ajami 1988, p. 140; Chubin and Tripp 1996, p. 33; Fuller 2007) have asserted that the majority of citizens in Bahrain are Shi'a. Further studies have claimed that this majority is as high as 70\% (Bahry 1997, p. 50; Bahgat 1999, p. 82; Nasr 2006, p. 59; Kamrava 2013, p. 5; Nuruzzaman 2013, p. 367; Wehrey 2013, pp. 113, 116). Irrespective of this, no official figures on this point have been released by the Bahraini government. Bahraini society is also divided into several ethnic and sectarian components. First, there are the Sunni Arabs, who are widely known to be 'tribal'. These include the Al Dosari, Al Rumaihi, and $\mathrm{Al} \mathrm{Jalahmah} \mathrm{families.} \mathrm{Second,} \mathrm{there} \mathrm{are} \mathrm{the} \mathrm{Sunni} \mathrm{Farsi,} \mathrm{known} \mathrm{as} \mathrm{'Hawala'}{ }^{4}$. Third, there are the Shi'a Arabs, known as 'Bahranis', who came to Bahrain from Al Hasa and Qatif in the Eastern Province of Saudi Arabia (Al Kaddrt 2014, p. 23) as a result of Wahhabi activity (1703-1792) ${ }^{5}$. Fourth, there are the Shi'a Farsi, referred to as the 'Ajami', and they make up 20\% of Bahrain's population (Diri 2009) and have moved to Bahrain over the past 60 years. However, Said (2016) and Diri (2009) argue that the Ajam were in Bahrain before the dawn of Islam and lived in peace with other Arab tribes. It has in fact been suggested (Karimi 2015, p. 11) that there is a political hierarchy among these groups in terms of social prestige, political positions, and job opportunities, whether on an official or public level, since each group seeks to protect its interests and rights in the State. However, the distinction between these categories is linked to the regional environment and sectarian division between Sunnis and Shi'a in the Middle East and North Africa (MENA) region, rather than local disputes (Karimi 2015, p. 11). Bearing this in mind, the structure of nation-building based on identity has accelerated the dissonance between the Shi'a groups and authority.

The Shi'a opposition appeared in Bahrain after the 1979 Iranian Revolution, deriving its strength, ideological interdependence, and financial support from Tehran. Thus, according to Mavani (2013) and Fahmy (2011), it has been widely claimed that Shi'a factions have been exporting the Iranian Revolution to Bahrain since the beginning of the 1980s. Cordesman (1997, p. 41) argues that:

4 'Hawala" means 'transfer' and is the name given to an Arab tribe, which moved continually from the coast of the Arabian Peninsula to the coast of Iran. This was due to three reasons, the first being political, namely war and conflict; the second being economic, due to trade and the transportation of goods; and finally, on humanitarian grounds to obtain food and water. See: Ansari (2011) The History of the Arab Hawala'and Utube Tribes'. Beirut: Dar Arab Encyclopedias, pp. 6-7.

5 Muhammad ibn Abd Al Wahhab launched a redress movement in the Najd; defending the purge of common Sufi and Shi'a worship such as the intercession of saints. The Wahhabi movement rose up against the tribes or states that opposed its creed such as Shi'a groups living in eastern Saudi Arabia (Ruark 2017). 
the nationalist fall and the rise of Khomeini changed Iran's politics into the region; the Persian revolution appealed to some of Bahrain's Shi'a, and Iran's religious leaders had considerable influence because many of Bahrain's Shi'a clergy trained in Iran, and Bahrain had many Persian residents.

Before 1979, very few clerics engaged in political activity because the majority of religious leaders used to believe that they must not be involved in any political system, but after the Iranian Revolution, many Shi'a clerics and groups in Bahrain engaged in political action against the authority. As result of the Iranian ascendancy, many Sunni interviewees have accused Shi'a of loyalty to Iran ${ }^{6}$, thus exacerbating sectarian tension in Arab societies (Ulrichsen 2016). It should be kept in mind here that many Sunnis in Bahrain have the impression that Shi'a leaders have a distinct political relationship with Tehran because their party's leaders adhere to Wilayat Al Faqih (Barzegar 2008, pp. 49-56), which reinforces Sunni and Arab fears. Wilayat Al-Faqih refers to the role of clerics in the leadership of the nation through the administration of its affairs and management of Islamic government (Selim 2009). The Sunni elite in Bahrain believed that many Shi'a followed Ali Khamenei, the Supreme Leader of the Islamic Republic of Iran (Idris 2014). In addition, a large body of literature published by authors such as Alam (2004); Hinnebusch (2010); Abdullah (2013); Sinkaya (2015); Keynoush (2016); Ulrichsen (2016); and Ahmadian (2018) is dedicated to the way in which Iran's regional influence in MENA has intensified the political tension between the authority and Shi'a groups on a domestic level in Bahrain. A broader perspective has been adopted by Gause and Gause (1994, p. 30); Matthiesen (2012); Sadiki (2014); Gengler (2015); Christie and Masad (2013, p. 251); and Lacroix (2011), who argue that the political crisis between the Shi'a and authority from the 1980s until the 2011 crisis have had negative repercussions for the scope of the political rapprochement between the authority and Shi'a groups.

Shi'ite actors seek to preserve their religious identity and promote ties with Iran to ensure the survival of Shi'ism in Bahrain (Wehrey et al. 2009). Scholars such as Gause and Gause (1994); Wehrey et al. (2009); Matthiesen (2012); Lacroix (2011); and Gengler (2015) have investigated the influence of political relations between the Bahraini government and Shi'ite groups, but without looking at the repercussions of tensions between the Usuli and Akhbaris on the relation of authority with Shi'i society. Nevertheless, this dimension is very important, because it assists in understanding the extent to which the Shi'a of Bahrain support or oppose the authority.

\section{Rivalry between the Akhbaris and Usuli}

It is significant to explore the map of the Shi'ite community in Bahrain, which consists of diverse groups that differ in intellectual, ethnic, religious, and political terms. These differences have affected the relationship between them as well as their political behavior and religious tendencies, both locally and regionally. For example, Shi'ite Arabs have moved from Iraq and Saudi Arabia to Bahrain over the centuries, with Shi'ite Persians settling in Bahrain in more recent times. Furthermore, there are the Usuli and Akhbaris: religious groups, who uphold Imamate ${ }^{7}$ ideology, but have historical, political, social, and ideological differences between them, which have aggravated political tensions.

Akhbaris cleric like Mohsen Al Asfour publicly supported the government in the 2011 crisis, while the Usuli cleric Issa Qassim, who is considered the spiritual leader of Shi'ite opposition groups such as Al Wefaq, explicitly urged the people to protest against the authority. However, the Bahraini government has concerns about the religious, political, and ideological relationship between certain

6 Participant 12, Manama, 21 February 2017; Participant 13, Manama, 21 February 2017; Participant 28, Riffa, 18 March 2017; Participant 31, Riffa, 20 March 2017; Participant 39, Riffa, 2 April 2017; Participant 52, Hamad Town, 17 March 2017; Participant 53, Manama, 18 May 2017.

7 The Imamate was a Shi'a group that claimed that Ali had the right to inherit the Caliphate. They consequently made the Imamate their main issue of concern. Imamate Shi'a believed that there were 12 Imams descended from the sons and grandsons of Ali ibn Abi Talib, who deserved the Caliphate more than anyone else (Al Ridwany 2016). 
Shi'a opposition groups, Usuli clerics, and the Supreme Leader in Iran, with the authority claiming that the Supreme Leader interfered in Bahrain's internal affairs in the 2011 crisis by supporting Issa Qassim and Al Wefaq (Lynch 2016, p. 30). At this point, therefore, it is necessary to explain the differences between the Akhbaris and Usuli, in order to understand their impact on the authority and within the Shi' $i$ community. There are in fact extensive religious and political differences between the Akhbaris and Usuli; for example, there is a jurisprudential debate between these factions regarding the establishment of the Islamic State and the role of clerics in political action during the Imam's absence (Covillo 2008, p. 11). For example, opinions vary regarding the religious, political, and social necessity for Wilayat $A l$ Faqih in the modern era (Fayyad 2015, pp. 106-24).

The two most widespread branches of the Twelvers ${ }^{8}$ are the Akhbaris and Usuli, but this split did not take place immediately after the death of the Imams; instead, it evolved over a longer period. However, explaining the reality of fragmentation in the Shi'i community will help reveal the extent to which rivalry between the Akhbaris and Usuli has influenced relationships between Shi'a elites as well as identifying the ties between Shi'a groups, the authority, and Sunni movements.

As a result of religious and political differences, the Twelver Shi'a s in Bahrain are divided into two schools: the Akhbaris and Usuli. At one time, the historical Shi'a conflict between the Usuli and Akhbaris arose through a dispute between the clerics of Najaf and Karbala in Iraq (Fahmy 2008, p. 22). This followed a split that took place in the 18th century, rooted in a political and religious dispute between the Akhbaris and Usuli. The Akhbaris in Bahrain, who defend Arab identity, rely on historical texts and the Hadiths as a method of directing individuals and groups, while the Usuli in Bahrain, influenced by Persian identity, rely on the jurisprudence of clerics to guide individuals, communities, and nations. However, one former Shi'i cleric claimed that this was a jurisprudential, rather than political division ${ }^{9}$. Similarly, religious differences are considered to be the main causes of political rivalry between the Usuli and Akhbaris in Bahrain. The religious deviations between them are outlined below.

First, the Akhbaris do not believe that clerics should govern any political system, because this is haraam, according to the orders of Allah and the Imam, especially since the absent Imam is considered to be the only legitimate ruler (Ajami 1988, p. 37; Akhavi 2008, p. 645; Covillo 2008, p.11). Second, the Usuli encourage clerics to work with the authorities to protect the interests of the people and reduce corruption (Fayyad 2015, pp. 106-7). However, according to the Usuli, clerics must be independent of any political regime, in order to be able to resist actors, thus occupying an independent social class. As a result, clerics should not be used as a tool of contemporary governments or regimes (Covillo 2008, pp. 116-17). Third, one of the reasons for religious and political dissonance in the Shi'i community is the Wilayat Al Faqih ideology, which is rejected by many Akhbaris clerics. Principally, some Usuli clerics such as Sayyid Ruhollah Musavi Khomeini and Sayyid Ali Hosseini Khamenei have sought to cooperate with temporal authority and this has caused jurists to act as delegates of the Imam during his absence (Abdullah 2013, p. 52). Some Usuli consequently grant political powers to the clergy to manage Shi'a affairs in MENA, in the absence of the Imam. However, this has led to a religious rift and political division between the Usuli and Akhbaris. Wilayat Al Faqih has therefore been the subject of intense debate amongst the Akhbaris, whereby this ideology is considered illegitimate, because it violates the principles of Shi'i doctrine. Moreover, no one is infallible, aside from the absent Imam (Fayyad 2015, pp. 106-24).

Despite claims to unity, there are a number of serious criticisms as the Akhbaris argue that Wilayat Al-Faqih contradicts Imamate ideology, because it is not permissible to form any Shi'ite state before the emergence of the absent Imam. The Akhbaris are therefore opposed to clerics engaging in political activities and do not support the establishment of a Shi'ite Stat, - this being rather a fundamentalist

8 Twelfth Imame/The Hidden Imam/Mahdi-Terms that refer to Mohammed Hassan Al Askari, who allegedly did not die. According to Shi'a belief, Al Askari will reappear in the future to establish righteousness and equality.

9 Participant 29, Manama, 16 March 2017. 
creation-because Wilayat Al-Faqih is not seen as representative of the absent Imam and the clergy are not infallible. Instead, Akhbaris believe that the Shi'ite community should only form a state at the appearance of the absent Imam, ${ }^{10}$ according to the 'doctrine of waiting'.

Fourth, according to the Akhbaris, believers should be satisfied solely with the guidance of the Imams. The Akhbaris depend upon the religious texts, legacy, and Hadiths [speeches] of the Imams as a source of legislation (Eliash 1979, pp. 12-16). In contrast, the Usuli concentrate on the jurisprudence, philosophy, and diligence of clerics as the methodology of Islamic law (Cole 1987, p. 196). Finally, the Akhbaris contradict the Usuli over many religious issues such as determining the dates of Eid and Tatbir ${ }^{11}$, and the practice of 'hitting the head with a knife' during Ashura (Mahfouz 2008).

Generally speaking, the religious differences between the Usuli and Akhbaris have become political rivalries. One Sunni scholar argued that some Akhbaris place an emphasis on containing Usuli expansion by warning adherents not to read Usuli literature or listen to their scientists, meaning that it is not permissible to read Usuli books, as they contravene Islam ${ }^{12}$. However, according to several participants, the political and social role of the Bahraini Akhbaris began to shrink due to the weakness of Akhbaris clerics in Iraq, who do not get any kind of support from Arab regimes for sectarian reasons (Al Khamis 2011) ${ }^{13}$. Thus, most Bahraini Shi'a follow Usuli Marjiyah ${ }^{14}$ abroad because there is no prominent Akhbari Marjiyah in Bahrain or Iraq ${ }^{15}$. In addition, many of the Bahraini Akhbari clerics who go to Najaf and Karbala for religious titles have been influenced by the Usuli literature because of the shortcoming of the Akhbaris' educational curriculum (Fahmy 2011, p. 53) ${ }^{16}$. In addition, Iran founded many religious Hawza (school) that graduate clerics who believe in the trend of Usuli. Although some Akhbaris in Iraq have resisted the hegemony and domination exercised by the Usuli and tried to prevent them from dominating Shi'i society (Yateem 2016, pp. 236-35) ${ }^{17}$, Iran in that context, has also tried to influence the Shi'a in the MENA by increasing the number of their followers in Najaf and Karbala (Fayyad 2015, pp. 117-22), thus strengthening Usuli leverage in Bahrain ${ }^{18}$.

The Usuli spread their ideas, approaches, and principles in Bahrain, Saudi Arabia, Kuwait, Iraq, and Lebanon through media channels sponsored by Iran to boost their influence in Arab societies, while many Arab states do not allow the Akhbaris to establish any media channel because of mistrust and fear of increasing Shi'a influence ${ }^{19}$. The sympathy of the Shi'a with the principles of the Islamic Revolution in Iran and Khomeini's speeches led to an increase in the followers of Usuli (Fahmy 2007, p. 35). Some Shi'a parties and clerics such as Issa Qassim have sought to gain support from Khomeini to be popular and legitimate in the Bahraini Shi'i community ${ }^{20}$.

However, Akhbaris have tried to contain the influence of Usuli organizations and clerics by exploiting religious events and activities (Yateem 2016, p. 241). Despite Akhbari efforts, what is important in this context is the influence of the competition between the Usuli and Akhbaris on the Shi'i community in Bahrain, because it will shed light on how the authority have cooperated with

10 Like the messianic violence of creation, Shi'ites believe that the Hidden Imam (Muhammad ibn Al-Hasan ibn Ali) will appear at the end of time to wipe out ignorance, non-Islamic laws, and injustice. Moreover, he will spread justice, morals, rights, and Islam by fighting the enemies of Islam (Al Kawthar TV 2018).

11 During Ashura, Shi'a from all over the Islamic world observe Tatbir to pay homage to Hussein by injuring themselves with a sword or knife (Hubbard 2014).

12 Participant 39, Riffa, 2 April 2017.

13 Participant 16, Muharraq, 27 February 2017; Participant 19, Manama, 6 March 2017.

14 The term Marjiyah is used to refer to clerics who are responsible for all the affairs and interests of the Shi'i community, serving as deputies of the Imam. This then gives them religious authority over the community, according to religious texts such as the Quran, the commandments of the Imam, and the Hadiths (Mavani 2013, p. 212). This is based on their legitimacy, which is derived from the absent Imam (Mavani 2013, p. 212).

15 Participant 16, Muharraq, 27 February 2017; Participant 19, Manama, 6 March 2017.

16 Participant 16, Muharraq, 27 February 2017; Participant 19, Manama, 6 March 2017.

17 Participant 16, Muharraq, 27 February 2017; Participant 19, Manama, 6 March 2017.

18 Participant 16, Muharraq, 27 February 2017; Participant 19, Manama, 6 March 2017.

19 Participant 16, Muharraq, 27 February 2017; Participant 19, Manama, 6 March 2017.

20 Participant 16, Muharraq, 27 February 2017; Participant 19, Manama, 6 March 2017. 
the Akhbaris to enhance their affinity with the Shi'i community (Yateem 2016). However, Cole (1987, pp. 186-93) argues that the Usuli have become more widespread in Bahrain, because of Iranian religious support for Usuli elites on the archipelago, from the time of Shah Ismail Safavi of Iran in 1524, up until the 18th century. In the New Sectarianism: The Arab Uprisings and the Rebirth of the Shi'a-Sunni Divide, Geneive Abdo (2017) said:

At the time, Bahrain was an important center for the Arab Shi'a, along with Jabal Amil in Lebanon and Kufa and Najaf in Iraq. All these places became centers of learning for the newly formed Safavid state in Iran, which needed to educate its Shi'a clerics. In fact, the first Safavid shah cleared his rulings with clerics in Najaf and Bahrain to ensure their theological validity.3 It is this history that the Sunni government and its loyalists use today when they brand the Shi'a opposition as "Safavid loyalists of Iran. (Abdo 2017)

In his introduction to the history of the Usuli, Saeed $(2008$, p. 50) highlights the fact that Shah Ismail Safavi of Iran claimed to be the deputy of the absent Imam. Shah Ismail also used clerics to spread Shi'ism in society and gave them the highest political positions to reinforce the regime's legitimacy. Meanwhile, in contemporary history, many Sunnis believe that Shi'i clerics such as Issa Qassem and Abdul Amir Al Jamri to be among the most important Usuli leaders in Bahrain and that they are supported by Iran.

\section{The Battle against Iran's Followers}

Issa Qassem and Abdul Amir Al Jamri were influenced by Usuli ideology and Wilayat Al Faqih while studying in Najaf and Qom from the 1980s until the end of the 1990s (Talawi 2016, p. 76). One of the Nationalist leaders interviewed explained that Issa Qassem and Abdul Amir Al Jamri did not oppose the authority in Bahrain before the Iranian Revolution, but subsequently became Usuli and adopted Wilayat Al Faqih ${ }^{21}$. According to one Shi'i scholar, these clerics then became the most prominent leaders of the Shi'a opposition, because they were among the main figures to expose the government and receive financial, religious, and political support from Iran. They also controlled many charities, thus bolstering their political power and financial independence ${ }^{22}$. Another Shi'i scholar suggested that Usuli clerics such as Issa Qassem and Abdul Amir Al Jamri have encouraged Shi'a to become involved in the political process, in order to satisfy the interests and rights of the sect ${ }^{23}$, whether through participation in Parliament or the formation of parties and lobby groups since 1979. As a result, Usuli and Iranian influence has been reinforced in the Shi'i community and Bahraini Shi'a have been influenced by Persian clerics because many Usuli clerics come from Iran, and most Usuli literature is written in Farsi (Abdullah 2013, p. 52). Therefore, although Akhbaris, Arab, Saudi Arabia, and Sunni fears over the growing influence of Iran and Usuli clerics cannot be measured, these fears are certainly evident when talking to the man on the street. In one interview on Al Arabiya television, Saudi Crown Prince Mohammed Bin Salman claimed:

How do I agree [ ... ] with a regime that is convinced that it is based on an extremist ideology, enshrined in its constitution and Khomeini's recommendation that Iran must be controlled by Muslims [ ... ] and [which has] spread their Twelver Jaafari doctrine throughout the Muslim world until the Mahdi appears[?]. (Al Saud 2017)

This statement shows the ideological differences between Saudi Arabia and Iran, and the impact of identity on bilateral relations. The repercussions of the rivalry between Tehran and Saudi Arabia have not only affected the local environment of both countries, but these effects have crossed many

\footnotetext{
Participant 14, Manama, 22 February 2017.

Participant 29, Manama, 16 March 2017.

Participant 29, Manama, 16 March 2017.
} 
regional borders, reaching Bahrain. The Iranian Revolution gave rise to issues of stability and security in Bahrain, especially within the scope of sectarian conflict in the geopolitical context.

On 14 March 2011, Saudi Arabia and other the Gulf States helped to ensure the stability and security of Bahrain in 2011 by sending military forces (Seikaly and Mattar 2014, p. 40), with a view to containing the uprising of Shi'a opposition groups that follow Usuli clerics such as Issa Qassim. Saudi intervention in Bahrain's political affairs actually influenced the political relationship between the government and Usuli clerics, where the involvement of Saudi Arabia empowered the authority and weakened the power of the opposition groups and some Usuli clerics like Issa Qassim, who mobilized the street against the government during the 2011 crisis. In addition, this intervention was not an easy decision for the Saudis, but rather one based on identifying a potential danger to Saudi Arabia and indeed, to the future of all Arabs, because any political change in Bahrain for the benefit of Shi'ite groups and Usuli clerics was likely to strengthen the Iranian influence that threatened Arab national security (Inbar 2013, p. 18; Sadiki 2014, p. 136) as well as Akhbaris clerics from the Al Stari, Al Asfour, and Al Madani families who allied with the government.

Shared religious and historical links mean that there is the general perception of Issa Qassim, who belongs to the Usuli school of thought, as operating under the guidance of the Supreme Leader. In order to analyze this debate in detail, some of the participants were of the opinion that there was an increasing tendency in Iran to embrace Usuli thought and this had correspondingly led to the rise of the Usuli in Bahrain, pointing to an ideological correlation (Abdo 2017; Fahmy 2011). Several Sunni participants considered that the rise of Iran as a Shi'ite State had increased Usuli influence in Bahrain, with Iran giving financial support to Usuli clerics, so that they could increase their following, establish religious schools, and promote Usuli thought in the country. Several interviewees claimed that Iran promoted itself as a Shi'ite State, seeking to defend the rights of Shi'ite in the region. Therefore, many Shi'ite in Bahrain sympathize with Wilayat Al-Faqih and embraced the principles of the Usuli School ${ }^{24}$.

Arab Shi'a have been influenced by Persian identity in many cultural and political areas, for example, Arab Shi'a do not observe Ashira (a religious occasion) ${ }^{25}$, because they only acknowledge temporary mourning. Persians have spread the culture of Ashira in Bahrain, Saudi Arabia, Kuwait, Iraq, and Lebanon such as hitting the chest, Al tatbir by sword, and beating with chains. In addition, Usuli clerics have disseminated the principle of reverence and obedience to the clergy in Arab societies until the appearance of the absent Imam, which means that it is not permissible to oppose the clergy, because those who criticize them are criticizing Allah, the Prophet Muhammad, and the Imams (Al Khibaz 2005).

To contain the so-called 'Persian influence' on Arab Shi'a, some Akhbaris clerics seek to preserve Arab identity by rejecting Persian policies in Arab countries including Bahrain (Saeed 2008, p. 114). Even so, the Usuli cleric, Muhammad Fadlullah argues that there is no conflict between Persian and Arab clerics (Fadlallah 2007). However, the contradictory identities represent a key factor in the competition between some of the Akhbaris and the Usuli in leading the Shi'i community. It is widely considered that inconsistency between Arab and Persian identities commonly feeds political conflict within the same community, whereby the Usuli sought Bahrain's accession to Iran during the Referendum for Independence in 1971, while the Akhbaris fought for the independence of Bahrain (Fahmy 2011, p. 52). The rival identities of components of the Shi'i community in Bahrain have consequently deepened the political conflict between the Akhbaris and Usuli as well as strengthening

24 Participant 13, Manama, 21 February 2017; Participant 16, Muharraq, 27 February 2017; Participant 19, Manama, 6 March 2017; Participant 20, Muharraq, 7 March 2017; Participant 21, Muharraq, 7 March 2017; Participant 23, Manama, 8 March 2017; Participant 26, Hamad Town, 11 March 2017; Participant 29, Manama, 16 March 2017; Participant 31, Riffa, 20 March 2017; Participant 38, Satra, 30 March 2017; Participant 39, Riffa, 2 April 2017; Participant 41, Satra, 5 April 2017; Participant 42, Manama, 6 April 2017; Participant 55, Issa Town, 20 May 2017; Participant 60, Manama, 25 May 2017.

25 Ashira is collective actions and behaviors during religious occasions such as the Day of Ashura that shows sadness and sympathy for Hussein bin Ali, who was subjected to injustice. 
the links between the regime and Akhbaris elites due to common political interests in the State and the containment of the Usuli in Bahraini society.

To clarify the above, one member of $A l$ Wefaq explained that the authority in Bahrain had cooperated with some Akhbaris to contain Usuli groups, who had a religious link with Iran and used Shi'a youth to spread violence as a means of sabotaging society ${ }^{26}$. However, a member of the Al Wefaq Association argued that the government did not ally itself with all Akhbaris clerics, because not all Akhbaris were in fact pro-government. The authority was allied with some Akhbaris families, who were oriented toward the current government ${ }^{27}$. In this vein, a member of Bahraini youth in Al Wefaq and one Sunni scholar illustrated how the authority had strengthened its political relationship with some Akhbaris families such as the Al Stari, $\mathrm{Al}$ Asfour, and Al Madani, appointing them to political positions in the Shura Council, Jaafari (Shi'a) court, and Jaffaria Waqf Directorate, responsible for preserving mosques and mattams, and developing endowments in Bahrain ${ }^{28}$ (Abdel Rahim 2015, pp. 9-23). One Sunni scholar also claimed that key members of the clergy from these Shi'a families have become part of the fabric of the State as they were advisers to the King and through these ties, the authority had attempted to promote rapprochement with the Shi'i community ${ }^{29}$.

Few Akhbaris clerics from the Al Stari, Al Asfour, and Al Madani families have criticized some Usulis clerics such as Issa Qassim, who support the demonstrations against the government and do not call for dialogue with the Sunnis to promote stability in society (Mahfouz 2008). One of the most famous Akhbaris clerics in Bahrain today is Mohsen Al Asfour, who was the only Akhbaris observed to criticize Iran's interference in Bahrain in 2009, referring to Ali Akbar's statements about Bahrain being an Iranian province (Fahmy 2011, pp. 58-60). Al Asfour declared:

Bahrain was never the 14th province of Iran one day and had no representative in the Iranian parliament ... Bahrain is a sovereign country and a member of the United Nations, the Arab League and the Gulf Cooperation Council. (Al Asfour 2009)

Such statements intensified the dispute between the Usuli and Akhbaris and created political barriers between the Usuli and Al Asfour (Manamapost 2016), because many Usuli now consider Mohsen Al Asfour to be a traitor. However, Al Asfour issued a fatwa in 2011, criticizing the 'opposition' and asserting that the occupation of the Pearl Roundabout ${ }^{30}$ was illegal:

Anyone who believes that under the umbrella of the Revolution [it is permissible] to commit crimes and abuses, is a misguided perpetrator and a criminal. The occupation of the Roundabout is something that has no legal justification in Islam and whoever bears responsibility for killing innocents is the opposition leader. The occupation of the Roundabout and the blocking of roads is considered to be a sin and haram. (BNA 2011) Within this fatwa, Mohsen Al Asfour encouraged Shi'a youth to refrain from disobedience and refuse to engage in extremist Shi'a organisations, who were allied with Iran against the government. However, one Sunni scholar claimed that the differences between components of the Shi'i community strengthened the relationship between the government and the Akhbaris, which bolstered the convergence of authority with the Shi'a community ${ }^{31}$. The single most striking observation to emerge from the comparison of the data was that most of the Sunni participants believed the role of the Akhbaris in the process of nation-building and political stability in society to be positive.

26 Participant 35, Aker, 27 March 2017.

27 Participant 30, Nouedrat, 18 March 2017.

28 Participant 35, Aker, 27 March 2017; Participant 11, Manama, 20 March 2017.

29 Participant 31, Riffa, 20 March 2017.

30 The Pearl Roundabout-A roundabout in Manama, the capital of Bahrain. The opposition used this point as an arena for sit-ins against the authority in 2011. The government demolished the Roundabout on 18 March 2011, in order to prevent further sit-ins.

31 Participant 39, Riffa, 2 April 2017. 
Within this fatwa, Mohsen Al Asfour encouraged Shi'a youth to refrain from disobedience and refuse to engage in extremist Shi'a organizations, who were allied with Iran against the government. However, one Sunni scholar claimed that the differences between components of the Shi'i community strengthened the relationship between the government and the Akhbaris, which bolstered the convergence of authority with the Shi'a community ${ }^{32}$. The single most striking observation to emerge from the comparison of the data was that most of the Sunni participants believed the role of the Akhbaris in the process of nation-building and political stability in society to be positive, principally that the Akhbaris saw themselves as not extremist in their views of other political components of society. In contrast, many Usuli participants supposed that the political attitudes of some Akhbaris clerics toward the Shi'i community were very negative because of their political allegiance to the authority.

\section{Conclusions}

In addition to the above, the political ties between Shi'a elites have been affected by competition for identity between the Usuli and Akhbaris. The most striking result to emerge from the data is that the competition for identity among clerics in Bahrain is inseparable from regional rivalry with the Akhbaris, who defend Arab identity. The variations between Shi'a components, as a result of differences in religion and identity, have strengthened political relations between the authority and the Akhbaris, especially as the Usuli receive financial and moral support from Iran. It is widely perceived that the government has nevertheless benefited from the conflict between the Akhbaris and Usuli, giving positions to religious Akhbaris (pro-authority) leaders, thus promoting relations somewhat between the authority and a group of Shi'i society.

The Usuli are influenced by Persian identity, and they believe in the need to engage the clergy in political action to manage Muslim affairs and satisfy their interests. The Usuli have consequently sought to cooperate with Shi'a clerics in Iran, Iraq, and Lebanon to strengthen their influence, protect their political interests, and disseminate their beliefs or identity. This has increased tensions between them and the authority and with the Usuli (Saeed 2008, p. 50; Abdullah 2013, p. 52; Fayyad 2015, pp. 117-22; Talawi 2016, p. 76). On the contrary, the Akhbaris mostly seek to protect Arab identity in the Shi'i community and do not wish to engage in political work until the emergence of the absent Imam, because their particular religious interpretation forbids it. However, some Akhbaris seek to contain the influence of the Usuli by cooperating with the authority and with Shi'a clerics in Iraq and Lebanon, in order to secure their survival. The authority has consequently provided political and financial support to some Akhbaris, in order to strengthen relations with the components of the Shi'i community. Therefore, the Akhbaris have become a key element of the State's structure and ongoing construction.

One interesting finding is, in modern history, it is widely believed that the Usuli have played a dominant role in Bahraini society, especially since the success of the Iranian Revolution. In particular, the Marjiyah have political roles across borders, which threaten state sovereignty. Meanwhile, Wilayat Al Faqih, which is integral to the Usuli school, has been considered as one of the primary factors that strengthen the link between Shi'a groups in Bahrain and the religious leadership, whether in Iran or Iraq, thus challenging state sovereignty even further. Furthermore, the argument of the paper is highly detailed and can be generalized to many states in the MENA such as Kuwait, Saudi Arabia, Iraq, and Lebanon, especially given the similarities in the normative environment and political conditions.

Nevertheless, the present study findings suggest that the authority have taken advantage of the conflict between the Akhbaris and Usuli by giving financial, political, and religious support to the Akhbaris, in order to secure the convergence of authority with the Shi'a community in the country. Thus, to strengthen the stability of the State, the authority should establish Alhawzat (Shi'i religious schools) in Bahrain for Akhbaris to increase the influence and numbers of clerics who adopt the Arab identity. The empowerment of Akhbaris clerics through the establishment of Alhawzat will improve

32 Participant 39, Riffa, 2 April 2017. 
the ties between the authority and Shi'i society and may reduce the numbers of clerics and groups who have been affected by the Usuli approach in Iran or Iraq. The Government should strengthen the influence of Akhbaris clerics by providing financial, media, cultural, and political support to create a comprehensive integration between authority and Shi'a political components. If the Akhbaris clerics gain many political benefits, the authority will be able to strengthen the state through cooperation with Akhbaris.

Funding: This research received no external funding.

Acknowledgments: I am thankful for my Simon Mabon who has a distinctive role in completing this paper through his guidance, advice and observations, which he was very gracious to me.

Conflicts of Interest: The authors declare no conflict of interest.

\section{Appendix A}

Table A1. Interviewee Demographics.

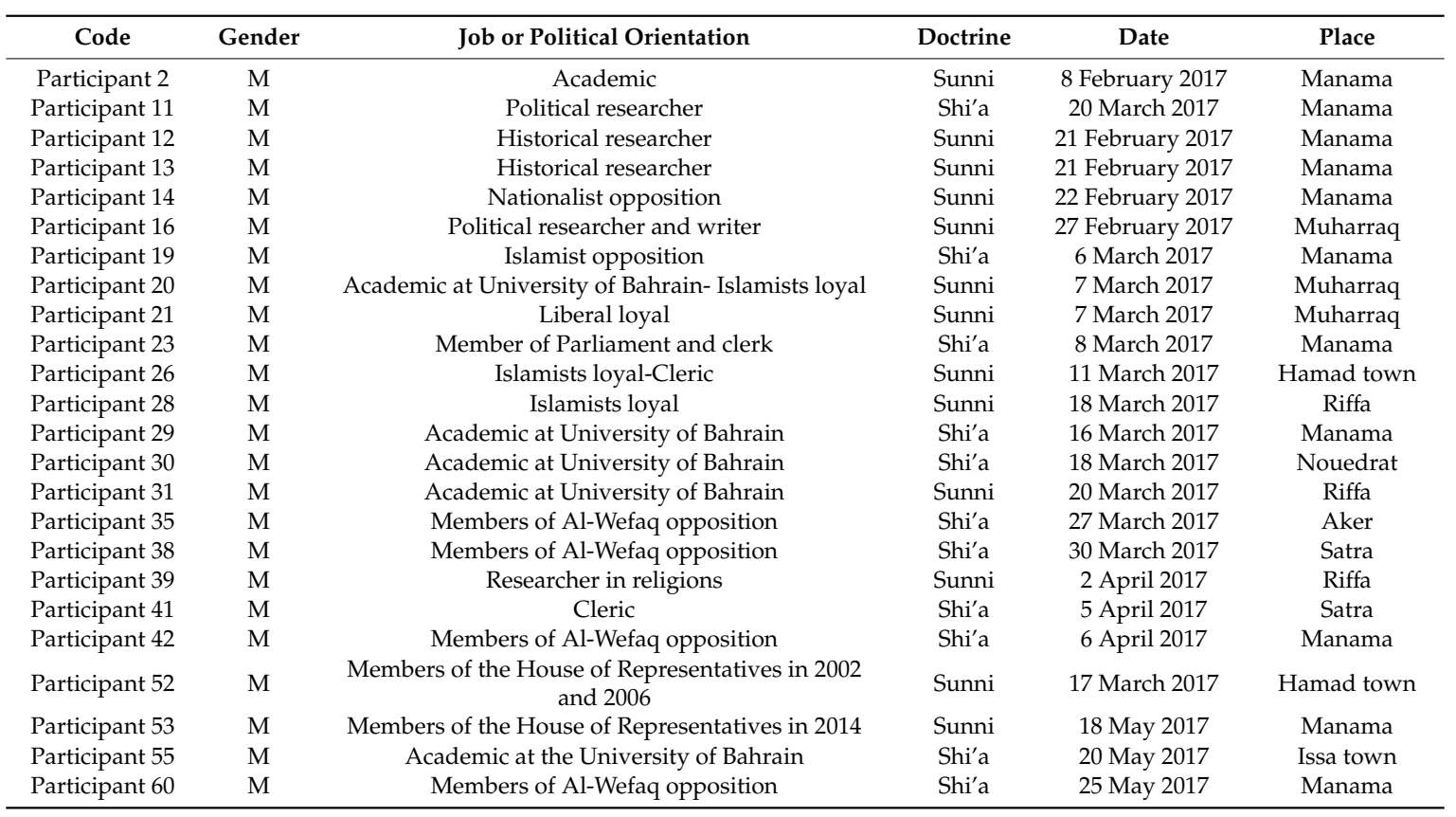

\section{References}

Abdel Rahim, Ahmed. 2015. Akhbaris and Fundamentalists Conflict within Twelver Shi'ism. Riyadh: Formation for Studies and Research.

Abdo, Geneive. 2017. The New Sectarianism: The Arab Uprisings and the Rebirth of the Shi'a-Sunni Divide. Oxford: Oxford University Press.

Abdullah, Adel. 2013. Engines of Iranian politics in the Gulf Region, 3rd ed. Dubai: Madarak Publishing House. Ahmadian, Hassan. 2018. Iran and Saudi Arabia in the Age of Trump. Survival 60: 133-50. [CrossRef] Ajami, Fouad. 1988. Iran: The Impossible Revolution. Foreign Affairs 67: 135-55. [CrossRef]

Akhavi, Shahrough. 2008. The thought and role of Ayatollah Hossein'ali Montazeri in the politics of post-1979 Iran. Iranian Studies 41: 645-66. [CrossRef]

Al Asfour, Muhsin. 2009. Crisis of Iranian Provocations around Bahrain and Call for Its Solution. Available online: Http://www.al-.asfoor.org (accessed on 6 June 2012).

Al Jazeera Media Network. 2017. Bahraini Document: Shi'a s Less than Half. Available online: http://www. aljazeera.net (accessed on 1 May 2018).

Al Kaddrt, Ahmed. 2014. The Political and Social Dimensions and Its Effects on The Political System in Bahrain (2002-2013). (The Supervision of Dr. Mahmoud Riad). Cairo: Al-Azhar University. 
Al Kawthar TV. 2018. Imam Mahdi (peace be upon him) appeared between Shiites and Sunnis. Available online: http://www.alkawthartv.com/news/120487 (accessed on 11 April 2017).

Al Khamis, Abdel Azeez. 2011. Iranian Fingers Pollute Political Conflict in Bahrain. Available online: http: //middle-east-online.com (accessed on 11 January 2018).

Al Khibaz, Mounir. 2005. The Influence of Persian Philosophy on Shi'ism. Available online: http://almoneer.org/ ?act=artc\&id=859 (accessed on 17 May 2018).

Al Ridwany. 2016. What Are the Most Prominent Shiite Sects that Have Emerged in Islamic History? Available online: https://www.alridwany.com (accessed on 16 May 2018).

Al Rumaihi, Muhammad. 1975. Bahrain a study on Social and Political Changes Since the First World War. Kuwait: University of Kuwait.

Al Saud, Muhammad. 2017. Muhammad Bin Salman: The Iranian Regime Is Based on an Extremist Ideology and Seeks to Control the Islamic World. Available online: https://www.youtube.com (accessed on 1 September 2019).

Alam, Shah. 2004. Iran-Pakistan relations: Political and strategic dimensions. Strategic Analysis 28: 526-45. [CrossRef]

Ansari, Jalal. 2011. The History of the Arab Hawala'and Utube Tribes'. Beirut: Dar Arab Encyclopedias.

Bahgat, Gawdat. 1999. Peace in the Persian Gulf: The Shi'is Dimension. Peace E Change 24: 369-78.

Bahry, Louay. 1997. The opposition in Bahrain: A Bellwether for the Gulf? Middle East Policy 5: 42. [CrossRef]

Barzegar, Kayhan. 2008. Iran's foreign policy in post-invasion Iraq. Middle East Policy 15: 47. [CrossRef]

Bill, James. 1984. Resurgent Islam in the Persian Gulf. Council on Foreign Relations 63. Available online: https://www.foreignaffairs.com (accessed on 1 September 2018). [CrossRef]

BNA. 2011. Sheikh Mohsen Al Asfour Criticizes the "Opposition" and Asserts that the Occupation of the Roundabout Is Illegal. Available online: http://www.bna.bh/portal/news/452095 (accessed on 5 May 2018).

Christie, Kenneth, and Mohammad Masad, eds. 2013. State Formation and Identity in the Middle East and North Africa. Berlin: Springer.

Chubin, Shahram, and Charles Tripp. 1996. Iran-Saudi Arabia Relations and Regional Order. Oxford: Oxford University Press, Published for IISS.

Cole, Juan R. 1987. Rival Empires of Trade and Imami Shi'ism in Eastern Arabia, 1300-1800. International Journal of Middle East Studies 19: 177-204. [CrossRef]

Cordesman, Anthony. 1997. Bahrain, Oman, Qatar, and the UAE: Challenge of Security. Boulder: Westview press.

Covillo, Thierry. 2008. Iran the Hidden Revolution. Beirut: Farabi.

Diri, A. 2009. History of the Persian Race in Bahrain. Dialogue Center: Available online: http://aldairy.ws (accessed on 5 September 2017).

Eliash, Joseph. 1979. Misconceptions Regarding the Juridical Status of the Iranian 'Ulamā'. International Journal of Middle East Studies 10: 9-25. [CrossRef]

Fadlallah, Mohammed. 2007. Fadlallah: Extremism in "Ali and Imams" Kafr and Reject the Increase in the Athan. Al-Arabiya. Available online: https://www.alarabiya.net (accessed on 14 May 2018).

Fahmy, Ahmed. 2007. Hezbollah and Fell Mask. Riyadh: Bayan Center for Research and Studies.

Fahmy, Ahmed. 2008. Conflict of Interest in Mesopotamia. Riyadh: Al Bayan Magazine.

Fahmy, Ahmed. 2011. Bahrain Is a Volcano on an Island: An Analytical Study of Religious Shi'a Movements in Bahrain and Foreign Relations. Riyadh: Al-Bayan Center for Research and Studies.

Fayyad, Ali. 2015. Theories of Power in Contemporary Shi'a Political Thought. Beirut: Center of Civilization for the Development of Islamic Thought.

Friedman, Brandon. 2012. Battle for Bahrain: What One Uprising Meant for the Gulf States and Iran. World Affairs 174: 369-78.

Fuller, Graham E. 2007. The Hizballah-Iran Connection: Model for Sunni Resistance. The Washington Quarterly 30: 139-50. [CrossRef]

Gause, F. Gregory, and Gregory F. Gause. 1994. Oil Monarchies: Domestic and Security Challenges in the Arab Gulf States. New York: Council on Foreign Relations.

Gengler, Justin. 2015. Group conflict and political mobilization in Bahrain and the Arab Gulf: Rethinking the Rentier State. Bloomington: Indiana University Press. 
Harrison, Lisa. 2001. Political Research an Introduction. London: Routledge.

Hinnebusch, Raymond. 2010. The International Politics of the Middle East. Manchester: Manchester University Press. Hubbard, Ben. 2014. Bloody and Belittled Shi'a Ritual Draws Historic Parallels. Available online: https: //www.nytimes.com (accessed on 30 July 2017).

Idris, Mohammed. 2014. Three Facts Discovered by the Bahraini Elections. Egypt: The Arab Center for Studies and Research, Available online: http://www.acrseg.org (accessed on 1 June 2017).

Inbar, Efraim, ed. 2013. The Arab Spring, Democracy and Security: Domestic and International Ramifications. Abingdon: Routledge.

Kamrava, Mehran. 2013. Beyond the Arab Spring: The Evolving Ruling Bargain in the Middle East. London: C. Hurst \& Co. (Publishers) Ltd.

Karimi, Sawsan. 2015. The Ctizenship Future and Gulf Identity. Paper presented at Annual Meeting XXXV of development Forum: The Future of the Gulf Cooperation Council: The Social Dimension, Kuwait, Kuait, February 5-6.

Keynoush, Banafsheh. 2016. Saudi Arabia and Iran: Friends or Foes? Berlin: Springer.

Lacroix, Stéphane. 2011. Awakening Islam. Cambridge: Harvard University Press.

Lynch, Marc. 2016. The New Arab Wars: Uprisings and Anarchy in the Middle East. New York: Public Affairs.

Mabon, Simon. 2013. Saudi Arabia and Iran: Soft Power Rivalry in the Middle East. London: I.B. Tauris.

Mahfouz, Hassan. 2008. Controversy in Bahrain Regarding the Vision of the Crescent of Shawwal. Available online: Http://www.aljazeera.net (accessed on 11 June 2017).

Manamapost. 2016. What Does Mohsen Al Asfour Want? Available online: http://www.manamapost.com (accessed on 13 June 2017).

Matthiesen, Toby. 2012. Bahrain's Pearl Roundabout. Available online: http://foreignpolicy.com (accessed on 9 January 2018).

Mavani, Hamid. 2013. Khomeini's Concept of Governance of the Jurisconsult (Wilayat al-Faqih) Revisited: The Aftermath of Iran's 2009 Presidential Election. The Middle East Journal 67: 207-28. [CrossRef]

Ministry of Information Affairs. 2014. Population and Demographic Growth. Available online: http://www.mia. gov.bh (accessed on 15 May 2018).

Nasr, Vali. 2006. When the Shiites rise. Foreign Affairs, 58-74. [CrossRef]

Nuruzzaman, Mohammed. 2013. Politics, Economics and Saudi Military Intervention in Bahrain. Journal of Contemporary Asia 43: 363-78. [CrossRef]

Ruark, Michael. 2017. Abd al-Wahhab, shirk, and the destruction of Islam. Available online: https://michaelruark. wordpress.com (accessed on 30 July 2017).

Sadiki, Larbi, ed. 2014. Routledge Handbook of the Arab Spring: Rethinking Democratization. Abingdon: Routledge.

Saeed, Zaid. 2008. Shi'a Imamat Analytical Reading. Cairo: Wahba Library.

Said, Hassan. 2016. Sheikh Issa Ahmed Qassem. Foundations and Releases. Available online: http://www.aei.org (accessed on 11 January 2018).

Saldana, Johnny. 2015. Thinking Qualitatively: Methods of Mind. Thousand Oaks: SAGE Publication.

Seikaly, May, and Khawla Mattar. 2014. The Silent Revolution: The Arab Spring and the Gulf States. Berlin: Gerlach Press.

Selim, Mohammed. 2009. What is the rule of the jurist? Available online: http://www.shorouknews.com (accessed on 16 May 2018).

Sinkaya, Bayram. 2015. Saudi Arabia and Iran: Soft Power Rivalry in the Middle East. Insight Turkey 17: 250.

Talawi, Ahmed. 2016. Iran and the Middle East's Fundamentalist Struggle: Policies to Mainstream Regional Chaos and Iran's Role in It. Cairo: Message.

The UK National Archives. 1959. The UK National Archives, File No: 016154 G, References BA1083/4 (59), Iranian Community in Bahrain.

Ulrichsen, Kristian Coates. 2016. Foreign Policy in Iran and Saudi Arabia: Economics and Diplomacy in the Middle East. Edited by Robert Mason. London: I. B. Tauris.

UN Data World Information. 2018. United Nations Statistics Division. Available online: http://data.un.org (accessed on 26 May 2020).

Wehrey, Frederic. 2013. Bahrain's Decade of Discontent. Journal of Democracy 24: 116-26. [CrossRef] 
Wehrey, Frederic, David E. Thaler, Nora Bensahel, Kim Cragin, and Jerrold D. Green. 2009. Dangerous but Not Omnipotent: Exploring the Reach and Limitations of Iranian Power in the Middle East. Santa Monica: Rand Corporation.

Yateem, Abdullah. 2016. Bahrain Society and Culture. Beirut: Arab Institute for Studies and Publishing.

(C) 2020 by the author. Licensee MDPI, Basel, Switzerland. This article is an open access article distributed under the terms and conditions of the Creative Commons Attribution (CC BY) license (http://creativecommons.org/licenses/by/4.0/). 